\title{
騒音の伝 搬特性
}

山本 剛 夫*

\section{1. はしがき}

騒音のアセスメントを行うにあたっては, 音源のパ ワーレベル, 指向性, 距離減衰空, 気, 土地, 障害物 等による過剩減衰 (excess attenuation), 特異な気 象条件下における 異常伝搬等を把握する必要がある が，ここでは, 紙面の関係ああり, 距離減衰を中心に 説明したい.

\section{2. 点音源の距離減衰}

音源から遠距離の場合は，簡単な点音源による距離 減衰の計算方法が適用できる・いま，点音源の音響パ ワーを $\mathrm{W}(\mathrm{watt})$, 音源から任意の距離 $\mathrm{d}(\mathrm{m})$ の地 点における音の強さ I (watt $\left./ \mathrm{m}^{2}\right)$ は, 自由音場では 次式で示される.

$$
\mathrm{I}=\mathrm{W} / 4 \pi \mathrm{d}^{2}
$$

従って, 強さのレベル IL (dB) は,

$$
\begin{aligned}
\mathrm{IL}= & \mathrm{PWL}-20 \log _{10} \mathrm{~d}-10 \log _{10} 4 \pi \\
& \fallingdotseq \mathrm{PWL}-20 \log _{10} \mathrm{~d}-11
\end{aligned}
$$

となる・

ただし，PWL はパワーレベル（dB）である. 我々が日 常遭遇する程度の気温と気圧の変化では, 強さのレベル IL は, 音圧レベル SPL 亿等しいとおくことができ, 又, 実際に測定するのは音匠レベルであるから，以下 SPL で表わすとととする.

音源が指向性をあつ場合は，

$$
\mathrm{SPL}_{\theta}=\mathrm{PWL}+\mathrm{DI} \theta-20 \log _{10} \mathrm{~d}-11
$$

となる・

ただし, $\mathrm{DI} \theta$ は $\theta$ 方向への指向指数 (directivity index) で次式で定義される.

\begin{tabular}{|c|c|c|c|c|c|c|c|c|c|}
\hline \multirow{3}{*}{ 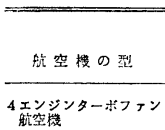 } & \multirow[b]{2}{*}{$0 !$} & \multirow{2}{*}{ 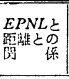 } & \multicolumn{7}{|c|}{ 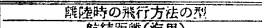 } \\
\hline & & & $\begin{array}{l}0- \\
500\end{array}$ & & & $\begin{array}{l}1500 \\
2500\end{array}$ & $\begin{array}{l}2500 \\
3500\end{array}$ & $\begin{array}{l}3500 \\
4500\end{array}$ & $4500^{+}$ \\
\hline & $\begin{array}{l}\text { Boeing } 707-320 \mathrm{~B}, \mathrm{C} \\
\text { Douglas DC-8- } 50,-8 \mathrm{~F},-60\end{array}$ & 园3. 3. & в & B & B & B & $\mathrm{c}$ & D & E \\
\hline 3 エンシシンターボフフン & Boeing $727-100,-200$ & 国3.3. & B & c & D & D & D & & \\
\hline 2 エンジンター亲フォン & $\begin{array}{l}\text { Boeing 737, Douglas DC-9 } \\
\text { BAC } 111\end{array}$ & 园3.3. & B & B & B & B & & & \\
\hline 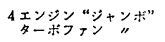 & Boeing 747 & 四3. 4. & B & B & B & B & c & $\mathrm{D}$ & E \\
\hline 新, 3エンンジン ” & $\begin{array}{l}\text { Douglas DC-10 } \\
\text { Lockeed } 1011\end{array}$ & 四3. 4 . & B & $\mathrm{c}$ & $\mathrm{c}$ & D & D & & \\
\hline 4エンジンピストン杜よ & $\begin{array}{l}\text { Douglas DC- } 6,-7 \\
\text { Lockeed Constellation } \\
\text { " Electra }\end{array}$ & 圆3. 5. & & & & PB & & & \\
\hline 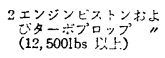 & $\begin{array}{l}\text { Convair } 340,440 \\
\text { Douglas DC-3 } \\
\text { Faiechild F-27 etc. }\end{array}$ & 53.5 & & & & $\mathrm{PA}$ & & & \\
\hline 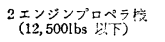 & $\begin{array}{l}\text { Piper Twin Comanche, } \\
\text { Aztec, Cessna } 310 \text {, etc. }\end{array}$ & [-13. 5. & & PC & & & & & \\
\hline $\begin{array}{l}\text { 1エンジンプロベラ留 } \\
\text { (180hp 以上) }\end{array}$ & $\begin{array}{l}\text { Beechcraft Bo:anza, } \\
\text { Cessna Skylane etc. }\end{array}$ & 囚3.5. & & PC & & & & & \\
\hline 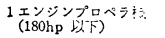 & $\begin{array}{l}\text { Cessna } 150,180 \\
\text { Piper Cherokee etc. }\end{array}$ & 凶凶is. 5. & & PD & & & & & \\
\hline
\end{tabular}

$$
\mathrm{DI}_{\theta}=\mathrm{SPL}_{\theta}-\overline{\mathrm{SPL}}
$$

表 $1 \mathrm{NEF}$ 計算のための航空機の分類

ただし, SPL $\theta$ は, 音源から任意の角 $\theta$ 方向に向って, 距 離 $\mathrm{d}$ の地点における音圧レベルで, $\overline{\mathrm{SPLs}}$ は，音源をと り囲む球（半径 d) の表面積 $4 \pi \mathrm{d}^{2}$ について，パワー 平均操作によって算出された平均音圧レベルである.

音源が地平面等にあり, 半球面波伝搬を示す場合は,

$$
\mathrm{DI}_{\theta}=\mathrm{SPL}_{\theta}-\overline{\mathrm{SPL}}+3
$$

となる.ただし, $\overline{\mathrm{SPL}_{\mathrm{H}}}$ は, 半球の表面積 $2 \pi \mathrm{d}^{2}$ につい て, パワー平均によって算出された平均音圧レベルであ る. (5)式より, 音源が, 均一な半球面波として, 音響エ ネルギーを放射しているときは，指向指数は，角 $\theta$ に 関係なく，一定の $3 \mathrm{~dB}$ となる. すなわち， $\mathrm{DI} \theta=\mathrm{DI}$ $=3 \mathrm{~dB}$ である.

(2)式あるいは(3)式より，

$$
\mathrm{SPL}=\mathrm{SPL}_{0}-20 \log _{10} \mathrm{~d} / \mathrm{d}_{0}
$$

が得られる.ただし, SPLoは音源から距離 do の地点 における音圧レベルで 既知とする. SPL は任意の距離 $\mathrm{d}$ の地点における音圧レベルである. (6)式より, 音源か らの距離が 2 倍になるごとに， $6 \mathrm{~dB}$ ずつ減衰するとと 


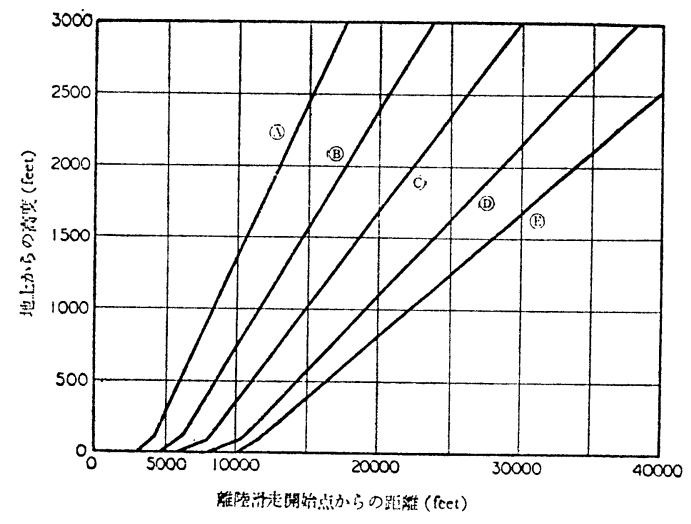

図-1 ジェット機の離陸時の一般的な飛行方法

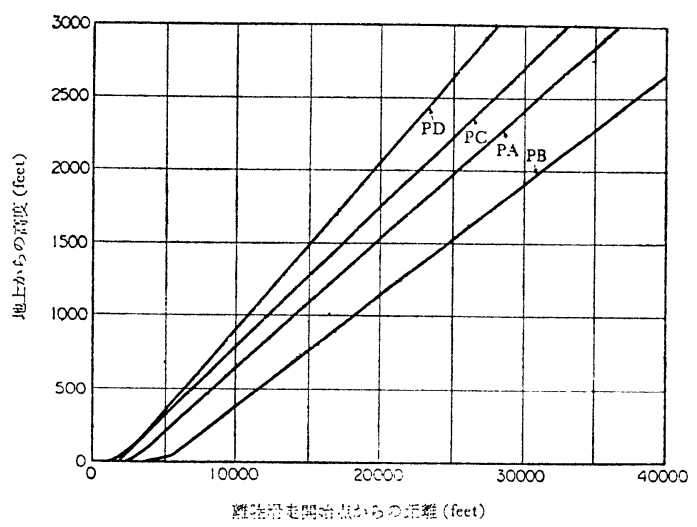

図-2 プロペラ機の離陸時の一般的な飛行方法

\section{がわかる。}

この点音源による距髉減衰は, 単一の航空機騒音ある いは単一の自動車騒音等のアセスメントに応用できる. ただし，航空機騒音の場合は，計算を簡略化するため， 機種之航続距離加ら離陸後の高度を求め, この高度のと

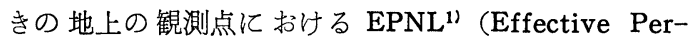
ceived Noise Level, 実効知覚騒音レベル, 単位 EPN dB）並びに，同様な手続きによる着陸時の EPNL を推 定し, 更に, 将来の航空機の運行計画に基づいて, 空港 周辺の騒音評価量（例えば，わが国では WECPNL ${ }^{11}$ (加重等価持続知覚騒音 レベル) アメリカでは $\mathrm{NEF}^{11}$ (騷音暴露予報) を推定する方法が採用されている.す なわち, 機種と航続距離から 表 $1^{2,3)}$ を用いて, 離陸時 の飛行方法の型を知り，ついで図1-2,3)，図-2,3) を用い $\tau$, 離陸滑走開始点加らの距離と, 先に求めた飛行方法 の型から, 航空機の高度を推定する. ついで, 観測点か ら飛行経路の地平面の正射影に，むしくはその接線に， 下した垂線の足までの距離之, 先に求めた高度から, 観

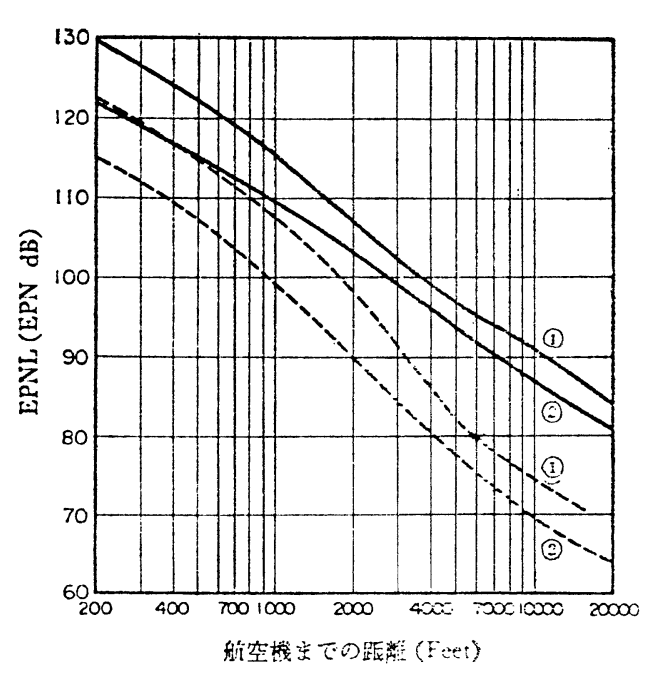

図-3 EPNL と距離との関係; 一一離陸, …....着陸 (1) 4 エンジン・ターボファン (B-707-320B, $\mathrm{C} ; \mathrm{DC}-8-50,-8 \mathrm{~F})$

(2) 2, 3 エンジン・ターボファン(B-737, DC-9, BAC 111, B-727-100, -200)

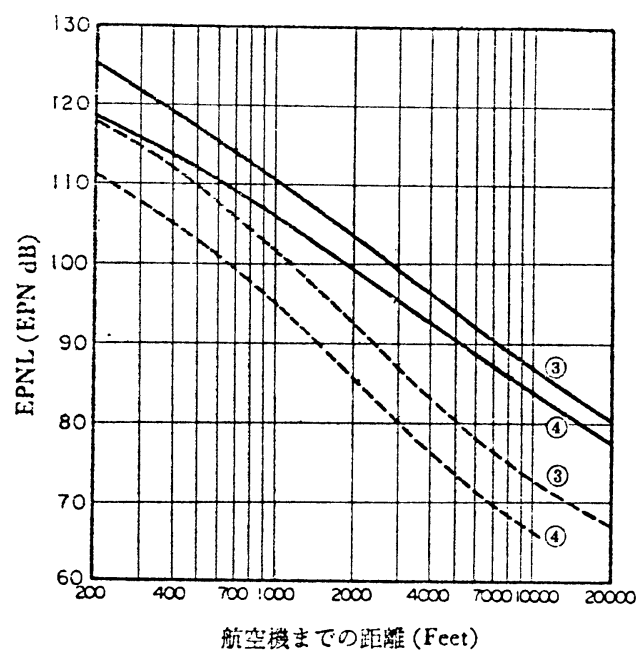

図-4 EPNL 々距離との関係; 一一離陸, …....着陸

(3) 4 エンジン“ジャンボ”ターボファン (B-747)

(4)新, 3 エンジン・ターボファン(DC-10, L-1011)

測点と航空機までの距離（slant distance）を求める. この距離が求まれれば, 図-3〜図-52,3) を用いて, 各機 種並びに離着陸別の 1 機あたりの EPNL が推定でき る. 従って, 飛行場付近のいくつ加地点について, 全 航空機のその点に及ぼす EPNL 在求め, 次式によって WECPNL を求めることができる。 


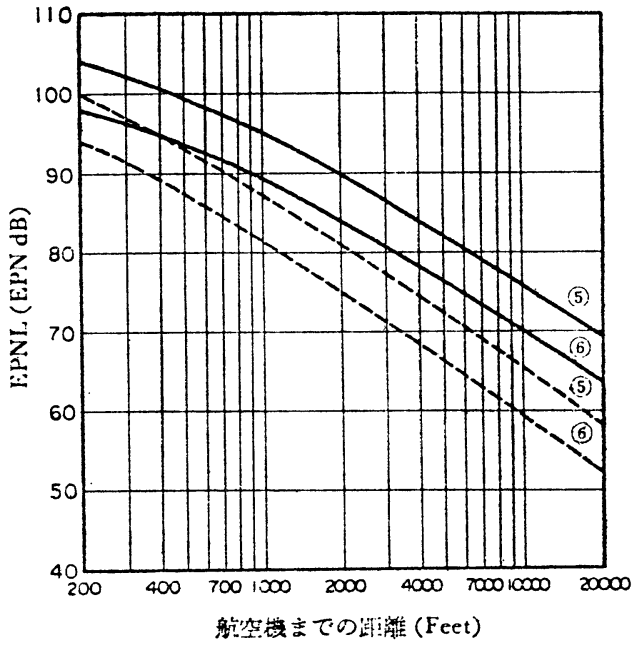

図-5 EPNL と距離との関係; 一一離陸, …...着陸

(5) 2,4 エンジンプロベラ機(最大総重量 12,500 LBS 以上)

(6) 1,2 エンジンプロペラ機(最大総重量 12,500 LBS 以下)

$$
\begin{aligned}
\text { WECPNL } & =10 \log _{10}(1 / \mathrm{N}) \sum_{1}^{\mathrm{n}} \operatorname{lantilog}_{10}(\operatorname{EPNL}(\mathrm{n}) / 10) \\
& +10 \log _{10}\left(\mathrm{~N}_{\mathrm{D}}+3 \mathrm{~N}_{\mathrm{E}}+10 \mathrm{~N}_{\mathrm{N}}\right)-39.4 \\
& \equiv \overline{\mathrm{EPNL}}+10 \log _{10}\left(\mathrm{~N}_{\mathrm{D}}+3 \mathrm{~N}_{\mathrm{E}}+10 \mathrm{~N}_{\mathrm{N}}\right)-39.4 \\
& \fallingdotseq \overline{\mathrm{L}_{\mathrm{A}}}+10 \log _{10}\left(\mathrm{~N}_{\mathrm{D}}+3 \mathrm{~N}_{\mathrm{E}}+10 \mathrm{~N}_{\mathrm{N}}\right)-27
\end{aligned}
$$

ただし， Nは航空機の 1 日の総運航回数で, $\mathrm{N}_{\mathrm{D}}, \mathrm{N}_{\mathrm{E}}$, $\mathrm{N}_{\mathrm{N}}$ は，それぞれ，1日のうちの昼間（0700～1900）, 夕方 $(1900 \sim 2200)$, 夜間 (2200〜0700) の運航回数を 示す. 従って, $N=N_{D}+N_{E}+N_{N}$ である. 又, $\bar{L}_{A}$ は $A$ 特性による騒音レベルのパワー平均である.

なお, 以上の方法を若干精密化するため, 観測点にお Vる航空機への仰角 ( $\beta$ ) が $90^{\circ}$ 以下の場合は, 機体に よる遮蔽の効果 $(\mathrm{Sh})$ を

$$
\mathrm{Sh}=3(1-\sqrt{\sin \beta}),(\mathrm{EPN} \mathrm{dB})
$$

として補正したり，あるいは，仰角が $30^{\circ}$ 以下の場合は， 地面による減衰 $(\Delta)$ を， $(\Delta 0 \cdot \gamma)$ として補正すること

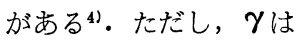

$$
\gamma= \begin{cases}\exp (-\sqrt{\tan 3 \beta}), & \beta<30^{\circ} \\ 0, & \beta \geqq 30^{\circ}\end{cases}
$$

であり, $\Delta_{0}$ (単位 $\mathrm{EPN} \mathrm{dB}$ ) は, 水平距離の関数とし て, 離陸時と着陸時とについて 図表が作製されている4 が，その概略を記載すると，離陸時では，水平距離が 400 feet 以下のとき $2 \mathrm{EPN} \mathrm{dB}$ (以下, 単位は略), 1000 feet で 6,2000 feet で 8,4000 feet 以上で約 10であり, 着陸時では, 約 200 feet で 2,400 feet で 3, 1000 feet で 7,2000 feet で12, 4000 feet 以上
で約15である. 又, 推力の\%の相違による補正を行うた めの図表4〕作製されているが記載は省略する.

なお，航空機騒音の環境基準は，WECPNL で，地 域の類型が I 類型（もっぱら住居の用に供される地域） の場合70以下, II 類型 (I 以外の地域であって通常の生 活を保全する必要がある地域）の場合75以下とされてい る.

\section{3. 道路交通騒音（点音源の集合）の距離減衰}

\section{1 等間隔モデル}

道路交通騒音の距離減衰を示す式のうち，最も簡単な あのは, 一車線等間隔・等パワーモデルである.このモ デルは, 当初, 我々の研究室 ${ }^{5)}$ で作製し，1963年に発表

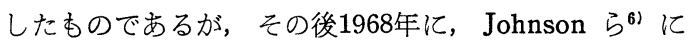
よって独立に導かれ，日本音響学会7,8) においても採用 されたものであるが, 図-6に示すように，無限に長い1

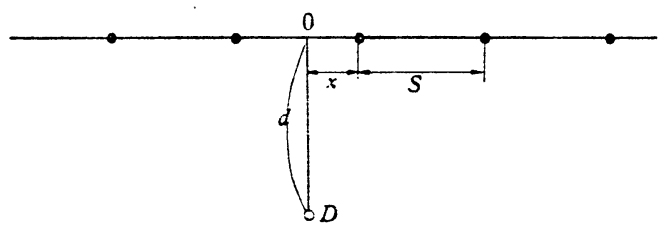

図-6 一車線等間隔モデル

車線上を，音響パワーを等しくする無指向性点音源とみ なせる車が，等閆隔で走行している場合を想定したもの である、いま，単一車輛から放射される音響パワーを $\mathrm{W}$ (watt)，受音点から車線までの距離を $\mathrm{d}(\mathrm{m})$, 車頭間 隔を $\mathrm{S}(\mathrm{m})$ ，測定点から車線に下した垂線の足（図-6の 0 点) から, 車の進行方向に向って最初の車までの距離 を $\mathrm{x}(\mathrm{m})$ とすれば，(1)式より，

$$
I=\sum_{n=-\infty}^{\infty} \frac{W}{4 \pi} \cdot \frac{1}{d^{2}+(x+n S)^{2}},\left(w a t t / m^{2}\right)
$$

となる，ただし， $\mathrm{n}$ は整数である，従って，音圧レベル は次式で示される.

$$
\begin{aligned}
\mathrm{SPL}=\mathrm{PWL}+ & 10 \log _{10} \frac{1}{4 \mathrm{dS}} \cdot \\
& \frac{\sinh 2 \pi \mathrm{d} / \mathrm{S}}{\cosh 2 \pi \mathrm{d} / \mathrm{S}-\cos 2 \pi \mathrm{x} / \mathrm{S}}
\end{aligned}
$$

単一車輛が半球面波伝播をすると仮定すれば，(11)式の右 辺の第 2 項中の $4 \mathrm{dS}$ を $2 \mathrm{dS}$ にかえればよい. 日本音響 学会 ${ }^{7,8)}$ では, 半球面波伝播を仮定しているので, 以下 , 「半球面波伝播」として, SPL の最大値, 最低值, 平 均值, 中央值を求めると, 以下のとおりである. 
$S P L_{\max }=\mathrm{PWL}+10 \log _{10} \frac{1}{2 \mathrm{dS}}$.

$$
\frac{\sinh \frac{2 \pi d}{S}}{\cosh \frac{2 \pi d}{S}-1}
$$

$\mathrm{SPL}_{\min }=\mathrm{PWL}+10 \log _{10} \frac{1}{2 \mathrm{dS}}$.

$$
\frac{\sinh \frac{2 \pi d}{S}}{\cosh \frac{2 \pi d}{S}+1}
$$

$S P L_{\text {mean }}=P W L+10 \log _{10} \frac{1}{\mathrm{dS}}$.

$$
\frac{\sinh \frac{2 \pi d}{S}}{\cosh \frac{2 \pi d}{S}+\sinh \frac{2 \pi d}{S}}
$$

$\mathrm{SPL}_{\text {median }}=\mathrm{PWL}+10 \log _{10} \frac{1}{2 \mathrm{dS}} \cdot \tanh \frac{2 \pi \mathrm{d}}{\mathrm{S}}$

又, 車の走行速度を $\mathrm{V}(\mathrm{km} / \mathrm{h})$ とすれば，交通量 $N($ 台/h) は次式で示される.

$$
\mathrm{N}=1000 \mathrm{~V} / \mathrm{S}
$$

JIS Z 8731-1966では，騒音が不規則かつ大幅に 変動する場合は，中央值を採用することとしている ので, 日本音響学会 ${ }^{7,8)}$ は, (15)式加ら,

$$
\begin{aligned}
\mathrm{L}_{50}= & \mathrm{L}_{\mathrm{W}}-8-20 \log _{10} l \\
& +10 \log _{10}(\pi \cdot l / \mathrm{d} \cdot \tanh 2 \pi l / \mathrm{d})+\alpha
\end{aligned}
$$

という式を導いている. 多車線の場合は 1 車線について 求めた值をエネルギー的に加算すればよい.

ただし

$\mathrm{L}_{50}$ : 騒音レベルの中央值 $[\mathrm{dB}(\mathrm{A})]$

$\mathrm{L}_{\mathrm{w}} \quad$ ： 1 台の車から発生する騒音の $\mathrm{A}$ 特性による平

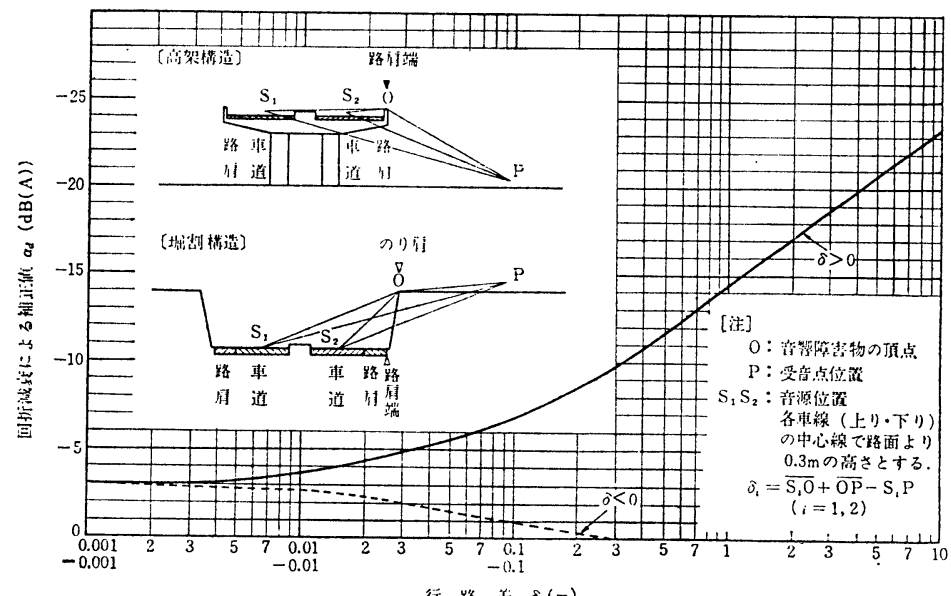

行 路 $\delta(\mathrm{m})$

図-7 回折減衰による補正值 $\boldsymbol{\alpha}$ 叶算図表

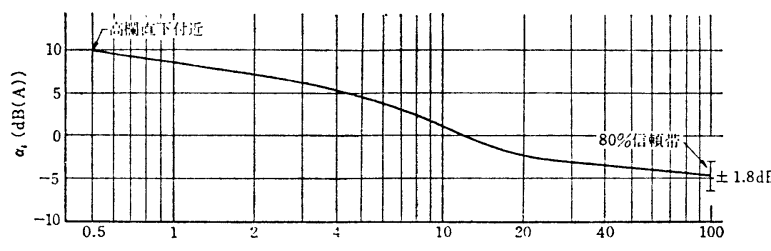

(a) 高架洋路

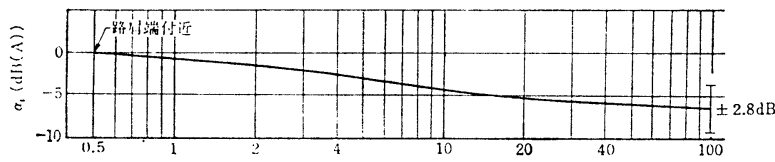

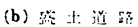

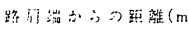

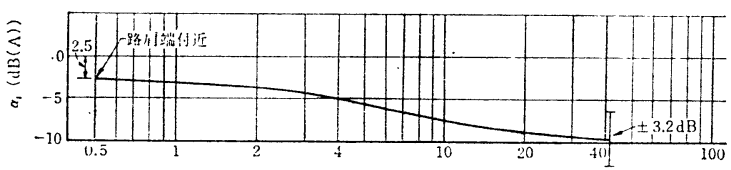

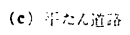

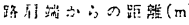

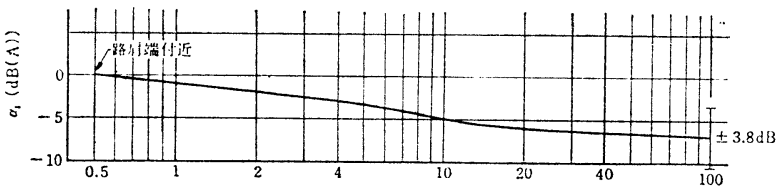

(d) 切士道路

図-8 補正值 $\alpha_{\mathrm{i}}$ の計算図表

均パワーレベル $[\mathrm{dB}(\mathrm{A})]$

$l$ : 車線から受音点までの距離 $[\mathrm{m}]$

$\mathrm{d}$ : 平均車頭間隔, $\mathrm{d}=1000 \mathrm{~V} / \mathrm{Q}[\mathrm{m}]$

$\mathrm{Q}$ : 交通量 [台/h]

$\mathrm{V}$ : 速度 $[\mathrm{km} / \mathrm{h}]$

$\alpha$ : 補正值（ $\alpha=\alpha_{\mathrm{d}}+\boldsymbol{\alpha}_{\mathrm{i}}, \boldsymbol{\alpha}_{\mathrm{d}}$ : 回折による 補正 值， $\alpha_{\mathrm{i}}$ : 沿道の地表条件など種々の原因によ る補正值)

である．今迄使用してきた記号と比較す ると, $\mathrm{SPL}_{\text {mean }} \rightarrow \mathrm{L}_{50}, \mathrm{PWL} \rightarrow \mathrm{L}_{\mathrm{w}}, \mathrm{d} \rightarrow l$, $\mathrm{S} \rightarrow \mathrm{d}, \mathrm{N} \rightarrow \mathrm{Q}$ 之変え, 若干の式の変形 を施こしたあのにほかならない，又， $\mathrm{L}_{\mathrm{w}}$ としては，車種構成を 2 分類とする 場合は，

$$
\begin{aligned}
\mathrm{L}_{\mathrm{W}}=87 & +0.2 \mathrm{~V} \\
& +10 \log _{10}\left(\mathrm{a}_{1}+10 \mathrm{a}_{2}\right)
\end{aligned}
$$

で， $a_{1}$ は小型車類混入率， $a_{2}$ は大型車 類混入率で， $a_{1}+a_{2}=1$ である。

車種構成を 3 分類とする場合は，

$$
\mathrm{L}_{\mathrm{w}}=85+0.2 \mathrm{~V}+10 \log _{10}
$$

$\left(b+3.2 b_{2}+16 b_{3}\right)$ 
で, $b_{1}$ は乗用車類混入率, $\mathrm{b}_{2}$ は小型貨物車類混入率, $\mathrm{b}_{3}$ は大型車類混入率で, $\mathrm{b}_{1}+\mathrm{b}_{2}+\mathrm{b}_{3}=1$ である.

ついで回折による補正值 $\alpha_{\mathrm{d}}$ を, 図一าによって求め, さらに, 道路構造別の補正值 $\alpha_{\mathrm{i}}$ を, 図-8によって推定 し，それぞれの值によって計算值を補正する・ただし以 上の計算方法は, 自動車専用道路又はこれに準ずる道路 を, 毎時約 1,000 台以上の自動車が毎時 $30 \sim 100 \mathrm{~km}$ 程度 の速度で定常的に走行しているとき，乙の道路から約 $100 \mathrm{~m}$ までの地点の騒音レベルの中央值を求めるために 用いられるあのであるとされている.

\section{2 指数分布モデル}

車頭間隔が等間隔でなく，より現実的な指数分布を示 す場合についても, 我々の研究室 ${ }^{9 \sim 11}$ で, その近似式が 求められた. 式の誘道は省略し, 最終の音圧レベル（騒 音レベルとしてもよい）の平均值 $\mathrm{SPL}_{\text {mean }}$, 分散 $\sigma \mathrm{x}^{2}$ の みを示せば以下のとおりである。

$$
\begin{gathered}
\text { SPL mean }=P W L+10 \log _{10} \frac{1}{4 \mathrm{~d} S}+\frac{10}{\log _{\mathrm{e}} 10} \\
\exp \left(\frac{4 \mathrm{~d} \pi^{\alpha}}{\mathrm{S}}\right) \mathrm{E}_{\mathrm{i}}\left(-\frac{4 \mathrm{~d} \pi^{\alpha}}{\mathrm{S}}\right) \\
\mathrm{x}^{2}=\left(\frac{10}{\log _{\mathrm{e}} 10}\right)^{2}\left[\frac{\pi^{2}}{2}-\left(\log _{\mathrm{e}} \frac{4 \mathrm{~d} \pi^{\alpha}}{\mathrm{S}}+\gamma\right)^{2}\right. \\
+2\left(\log _{\mathrm{e}} \frac{4 \mathrm{~d} \pi^{\alpha}}{\mathrm{S}}+\gamma\right) \cdot \mathrm{E}_{\mathrm{i}}\left(\frac{4 \mathrm{~d} \pi^{\alpha}}{\mathrm{S}}\right) \\
-\left\{\exp \left(\frac{4 \mathrm{~d} \pi^{\alpha}}{\mathrm{S}}\right) \mathrm{E}_{\mathrm{i}}\left(-\frac{4 \mathrm{~d} \pi^{\alpha}}{\mathrm{S}}\right)\right\}^{2} \\
\frac{\left(\sum_{\mathrm{r}=1}^{\mathrm{n}} \frac{1}{r}\right)^{2}+3 \sum_{\mathrm{r}=1}^{\mathrm{n}} \frac{1}{\mathrm{r}^{2}}}{\mathrm{n} !} \\
+\exp \left(\frac{4 \mathrm{~d} \pi^{\alpha}}{\mathrm{S}}\right) \sum_{\mathrm{n}=1}^{\infty} \\
\left.\left(-\frac{4 \mathrm{~d} \pi^{\alpha}}{\mathrm{S}}\right)^{\mathrm{n}}\right] \quad
\end{gathered}
$$

ただし， $\alpha=\frac{(\mathrm{d} \pi / \mathrm{S})^{2}}{1+(\mathrm{d} \pi / \mathrm{S})^{2}}$

で, $\mathrm{E}_{\mathrm{i}}\left(-\frac{4 \mathrm{~d} \pi^{\alpha}}{\mathrm{S}}\right), \overline{\mathrm{E}_{\mathrm{i}}}\left(\frac{4 \mathrm{~d} \pi^{\alpha}}{\mathrm{S}}\right)$ は積分指数関数, $\gamma$ は才 イラーの定数である. 又, 式(20)〜(22)中の記号は, 式(12)〜 (16)中のそれらと同様である.

指数分布モデルの場合の音圧レベルの平均値の距離に よる減衰と，等間隔モデルの場合のそれとを比較したも のが，図-9である．実線は指数分布モデルから導かれた 近似解〔式(20)]で，破線は等間隔モデルによる值[式(14)] で，白丸印は，モンテカルロ法によるシミュレーション 実験の結果である.シミュレーションの結果と, 式(20)に よる計算値とは極めて良い一致を示している．等間隔モ
デルによる結果と比較すると， d あるいは d/S が大き い場合は，両者間に䏩んど差はないが， $\mathrm{d}$ が小さくなる 之, 次第に差が生じ, $\mathrm{d}=2 \mathrm{~m}$ 地点では, 等間隔モデル による計算值の方が, 約 $3 \mathrm{~dB}$ 程大きい值を示す. 中央 值の場合屯，等間隔モデルの方が指数分布モデルよりや や大きい值を与えるが, 両者の差は, 平均值の場合より 小さい. 更にパワーレベルが, 平均值 $\mathrm{PWL}$ mean $(\mathrm{dB})$, 標準偏差 $\sigma(\mathrm{dB})$ の正規分布をするとすれば，受音点に おける音圧レベル（あちろん，騒音レベルとしてもよ い)の平均值は, 次式で示される ${ }^{11,12 i}$.

$$
\begin{gathered}
\mathrm{SPL}_{\text {mean }}=\mathrm{PWL}_{\text {mean }}+10 \log _{10} \frac{\mathrm{A}}{4 \mathrm{dS}}+\frac{10}{\log _{\mathrm{e}} 10} \cdot \\
\quad \exp \left(4 \frac{\mathrm{d}}{\mathrm{S}} \mathrm{A}^{-1 / 2}\right) \cdot \mathrm{E}_{\mathrm{i}}\left(-4 \frac{\mathrm{d}}{\mathrm{S}} \mathrm{A}^{-3 / 2}\right) \\
\text { ただし, } \mathrm{A}=\exp \left[\frac{\sigma^{2}}{2}\left(\frac{\log _{\mathrm{e}} 10}{10}\right)^{2}\right]
\end{gathered}
$$

等間隔モデル及び指数分布モデルの場合に適用できる

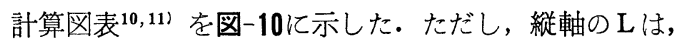

$$
\begin{aligned}
L & =S P L_{\text {mean }}-10 \log _{10} \frac{\mathrm{A}}{4 \mathrm{dS}} \\
& =S P L_{\text {mean }}-10 \log _{10} \frac{\mathrm{e}^{\frac{\sigma^{2}}{2}\left(\frac{\ln 10}{10}\right)^{2}}}{4 \mathrm{dS}}
\end{aligned}
$$

である.とくに，A特性を採用した場合のパワーレベル を $\mathrm{PWL}(\mathrm{A})$ とすれば,

$$
\mathrm{PWL}(\mathrm{A})_{\text {mean }}+10 \log _{10} \frac{\mathrm{e}^{\frac{\sigma^{2}}{2}\left(\frac{\ln 10}{10}\right)^{2}}}{4 \mathrm{dS}}=\mathrm{Leq}
$$

すなわち，等価騒音レベル (equivalent sound level) となる.

パワーレベルの平均值を $0 \mathrm{~dB}$ として, 音圧レベルの 平均值の距離減衰を, $\sigma=0$, 及び $\sigma=5 \mathrm{~dB}$ の場合につ いて計算した結果を, 図-11 亿示す. パワーレベルが正 規分布をするとして計算した值の方が, 数值が大きくな り，乙の差は遠距離になるほど著明となる.

なお，より一般的な車頭間隔の分布と考えられている アーラン分布についても, 我々の研究室で検討中である が, 現在, 音の強さの平均值と, 音の強さの分散が求め られた ${ }^{13)}$ 段階であり, 音圧レベルの平均值及び分散の 一般式は，まだ求められていないので省略する.

\section{4. 列車騒音の距離減衰（線音源, 連続二重音 源）}

\section{1 有限長線音源モデル}

列車を非干涉性の有限長線音源とみなせば，図-12 亿 


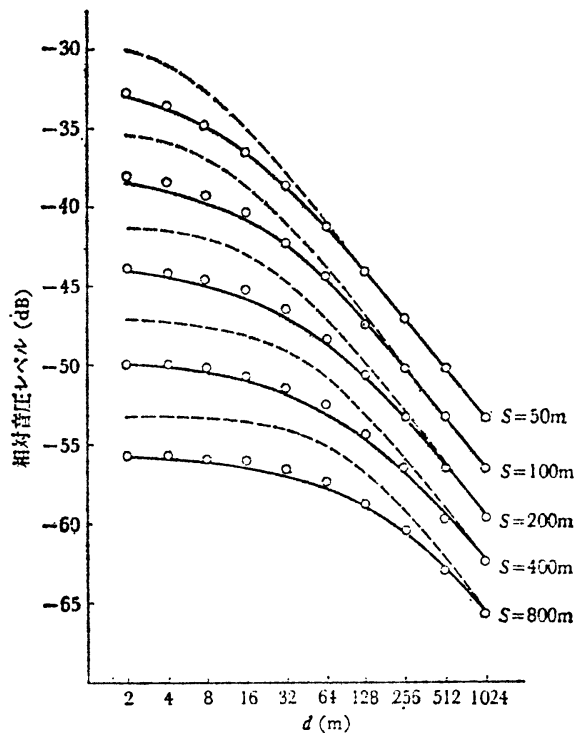

図-9 音压レベル $[\mathrm{PWL}=0 \mathrm{~dB}]$ の平均值の 距離 による減衰

白マル印はモンテカルロ法によるンミュレーンョ ンの結果, 実線は指数分布モデルから 導びかれた 近似解〔(20)式〕破線は等間隔モデルによる值

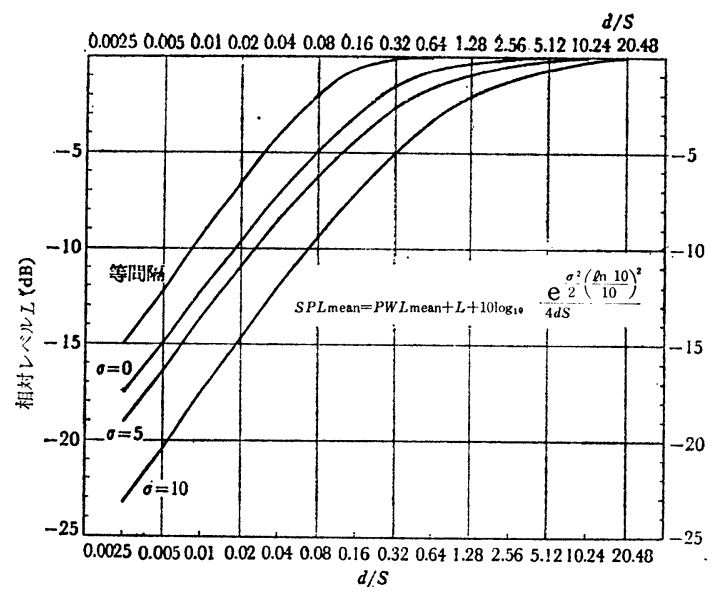

図-10 音圧レベルの平均值を求めるためのLの值 $\sigma$ はパワーレベルが平均 $0 \mathrm{~dB}$ の正規分布を する場合の標準偏差の値 (dB)

示す受音点 $\mathrm{P}$ における列車騒音の強さ IL は次式で示さ れる.

$$
\begin{aligned}
\mathrm{I}_{\mathrm{L}} & =\frac{\mathrm{W}_{\mathrm{L}}}{4 \pi} \int_{\mathrm{x}_{1}}^{\mathrm{x}} \frac{\mathrm{dx}}{\mathrm{d}^{2}+\mathrm{x}^{2}}=\frac{\mathrm{W}_{\mathrm{L}}}{4 \pi} \cdot \frac{1}{\mathrm{~d}}\left(\tan ^{-1} \frac{\mathrm{x}_{2}}{\mathrm{~d}}-\tan ^{-1} \frac{\mathrm{x}_{1}}{\mathrm{~d}}\right) \\
& =\frac{\mathrm{W}_{\mathrm{L}}}{4 \pi} \cdot \frac{1}{\mathrm{~d}}\left(\theta_{2}-\theta_{1}\right)=\frac{\mathrm{W}_{\mathrm{L}}}{4 \pi} \cdot \frac{\varphi}{\mathrm{d}}
\end{aligned}
$$

ただし， $W_{L}$ は単位長あたりの音源のパワーである. $\mathrm{X}_{1}, \mathrm{X}_{2}$ を図-7に示す $\mathrm{X}, \mathrm{L}$ で示すと,

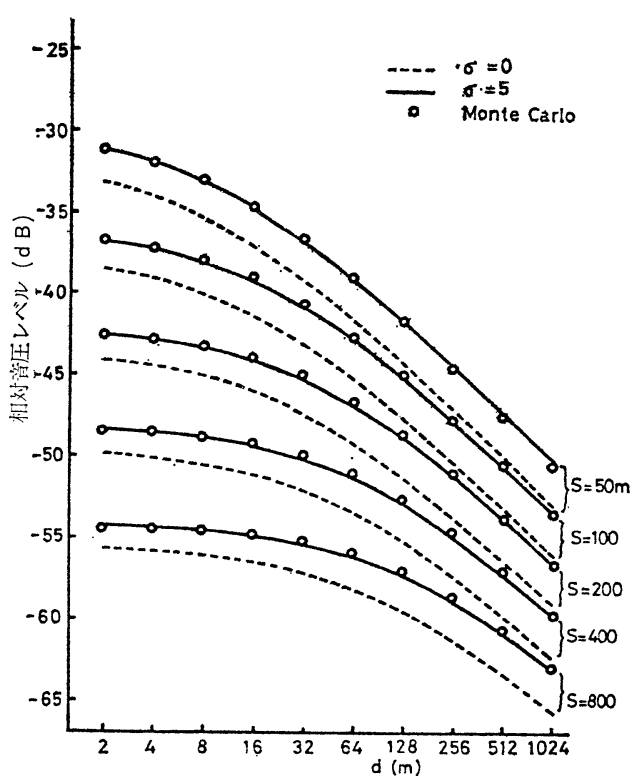

図-11 パワーレベルが分布する場合 $(\sigma=5 \mathrm{~dB})$ 之 しない場合についての音圧レベルの 平均值 $[\overline{\mathrm{PWL}}=0 \mathrm{~dB}$ のとき]の距離による減衰.

白丸印はシミュレーション計算 $(\sigma=5 \mathrm{~dB}$ の とき)の結果, 実線は(23)式において $\sigma=5$ $\mathrm{dB}$ としたときの值, 破線は $\sigma=0 \mathrm{~dB}$ とし たときの值.

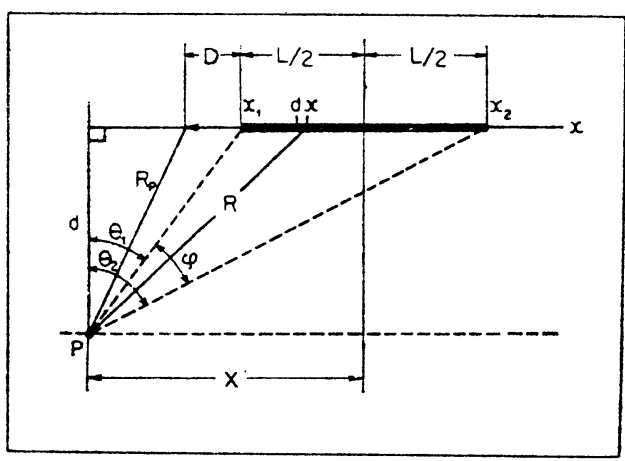

図-12 列車騒音の理論的 モデルに応用された列車 並びに観測点の幾何学的配置

$$
\varphi=\tan ^{-1} \frac{X / L+1 / 2}{d / L}-\tan ^{-1} \frac{X / L-1 / 2}{d / L}
$$

である. 従って音圧レベルは,

$$
\mathrm{SPL}_{\mathrm{L}}=\mathrm{PWL} \mathrm{L}_{\mathrm{L}}-10 \log _{10} 4 \pi+10 \log _{10} \frac{\varphi}{\mathrm{d}}
$$$$
=P W L_{L}-10 \log _{10} 4 \pi L+10 \log _{10} \frac{\varphi}{d / L}
$$ 
と表わすととができる.添字のLは線音源であ るととを示している. 式(29)に扔いて, 距離隇衰 に関連する頃は，右辺第 3 項のみであり，ての

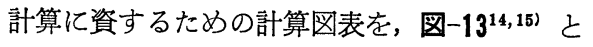
して掍載した. ピーク值を概算するには，dが $\mathrm{L} / \pi$ までは, 無限長線音源としての減衰, す なわち, 距離が 2 倍になるごとに $3 \mathrm{~dB}$ の減衰

$(-3 \mathrm{~dB} / \mathrm{dd}), \mathrm{d}$ が $\mathrm{L} / \pi$ より遠距離では, 点 音源としての減衰, すなわち, 倍距離 $6 \mathrm{~dB}$ の 減衰 $(-6 \mathrm{~dB} / \mathrm{dd})$ とすればよい。

速度の要因を加えるときには, $30 \log _{10}\left(\mathrm{~V} / \mathrm{V}_{0}\right)$ を加算する ${ }^{15)}$ ・ただし，道新幹線鉄の場合は， この補正項は $20 \log _{10}\left(\mathrm{~V} / \mathrm{V}_{0}\right)$ であるという(15).

\section{2 有限長線音源プラス点音源モデル}

強力なけん引力をもつ機関車独自の騒音を，とくに考 慮する必要があるときは, 機関車を点音源とみなし，さ きに求めた SPL $L$ に対し，エネルギー的に加算すれば よい，機関車騒音のパワーレベルを $P W L_{P}$ ，その音響 パワー重心 (acoustic power centroid) からの距離を $R_{P}$ とすれば，乙の場合の音圧レベル SPLP

$S P L_{P}=P W L_{P}-10 \log _{10} 4 \pi-20 \log _{10} R_{P}$

で示される.ただし，

$$
\mathrm{R}^{2}=\mathrm{d}^{2}+(\mathrm{X}-\mathrm{D}-\mathrm{L} / 2)^{2}
$$

である (図-12参照). 両者をエネルギー的に加算した音 圧レベル SPLLP は,

$$
S P L_{\mathrm{PP}}=10 \log _{10}\left(10^{\mathrm{SPL}_{\mathrm{L}} / 10}+10^{\mathrm{SPL} \mathrm{P} / 10}\right)
$$

となる，地面を完全反射と仮定するときは，式(29)，式(30) における $4 \pi$ を $2 \pi$ とすればよい。

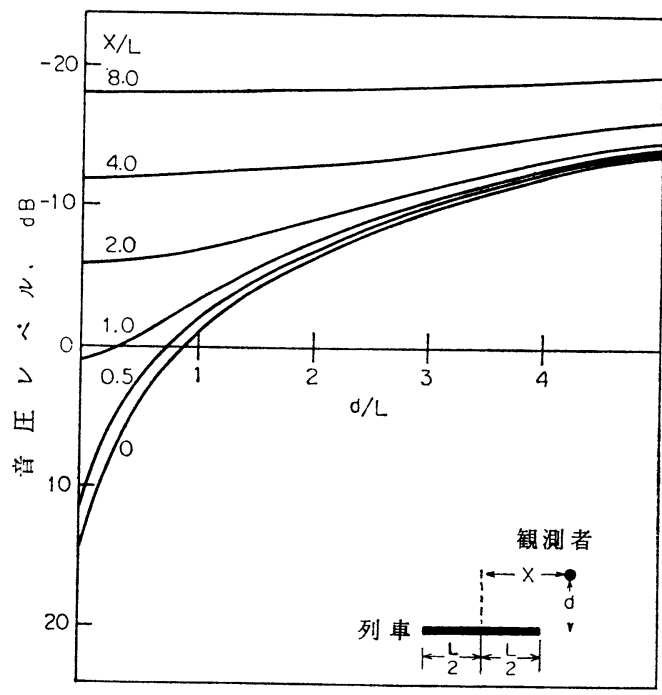

図-13 有限長線音源 モデルによる列車騷音の距離 減衰 $\left(10 \log _{10} \varphi / \mathrm{d} / \mathrm{L} \text { の值 }\right)^{1)}$

(30)

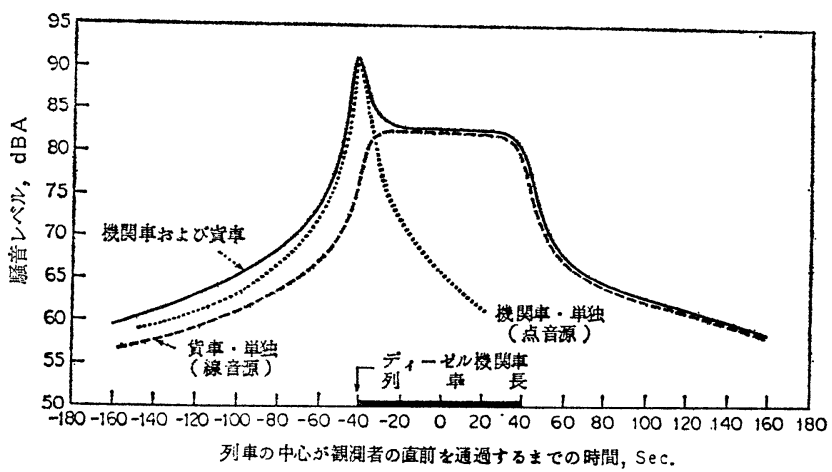

図-14 有限長線音源プラス 点音源モデルによる列車騒音の時間 的経過 ${ }^{14)}$

|32式に基づいて計算された貨物列車の騒音レベルの時 間的経過を図-14に示した14,15). ただし，計算条件は以 下のとおりである.

(1)有限長線音源とみなし得る列車の全長を， 3,500 feet $(1,067 \mathrm{~m})$ とし, 速度を $30 \mathrm{mile} / \mathrm{h}(48.3 \mathrm{~km} / \mathrm{h})$, 線路 から 100 feet $(30.5 \mathrm{~m})$ の地点での騒音レベルを 82.5 $\mathrm{dB}(\mathrm{A})$ とする.

(2)ディーゼル機関車の騒音レベルを, 100 feet (30.5m) 離れた地点で $91.1 \mathrm{~dB}(\mathrm{~A})$ とし, 機関車の音響パワー重 心の位置を，最初の列車より 75 feet $(22.9 \mathrm{~m})$ ほど先 端にあるとして計算したものである。

\section{3 連続二重音源モデル}

車輌の各車輪の位置にレールと直角方向の軸をもつ連 続二重音源モデル (有限長) が，井川16) によって提唱 されている．乙の場合，Wdを二重音源の単位長あたり のパワー，強さを Id とすれば,

$$
\begin{aligned}
I_{d} & =\int_{x_{1}}^{x_{2}} \frac{W_{d}}{4 \pi\left(d^{2}+x^{2}\right)} \cdot \frac{d}{\sqrt{d^{2}+x^{2}}} d x \\
& =\frac{W_{d}}{4 \pi d}\left[\frac{x}{\sqrt{d^{2}+x^{2}}}\right]_{x_{1}}^{x_{2}}
\end{aligned}
$$

となり（図-12参照)，音圧レベル $\mathrm{SPL}_{\mathbf{d}}$ は,

$$
\begin{aligned}
\mathrm{SPL}_{\mathrm{d}}= & \mathrm{PWL}_{\mathrm{d}}-10 \log _{10} 4 \pi-10 \log _{10} \mathrm{~d}+10 \log _{10} \\
& \left(\frac{1}{\sqrt{1+\left(\mathrm{d} / \mathrm{x}_{2}\right)^{2}}}-\frac{1}{\sqrt{1+\left(\mathrm{d} / \mathrm{x}_{1}\right)^{2}}}\right) \\
= & \mathrm{PWL}_{\mathrm{d}}-10 \log _{10} 4 \pi \mathrm{L}-10 \log _{10} \mathrm{~d} / \mathrm{L} \\
+ & 10 \log _{10}\left(\frac{1}{\sqrt{1+\left(\frac{\mathrm{d} / \mathrm{L}}{\mathrm{X} / \mathrm{L}+1 / 2}\right)^{2}}}-\frac{1}{\sqrt{1+\left(\frac{\mathrm{d} / \mathrm{L}}{\mathrm{X} / \mathrm{L}-1 / 2}\right)^{2}}}\right)(34)
\end{aligned}
$$

となる. 連続二重音源の場合は, 線路に直角方向の指向 性が強くなり（図-15，，かつ, 騒音レベルの立上り速度 が急峻になる (図-16). 新幹線騒音の場合は, 立上り速 


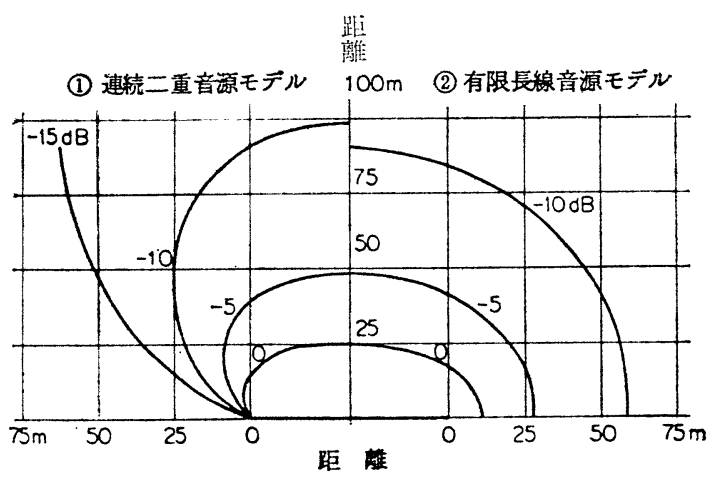

図-15 連続二重音源 モデルと有限長線音源 モデル との指向性の相違 ${ }^{17)}$

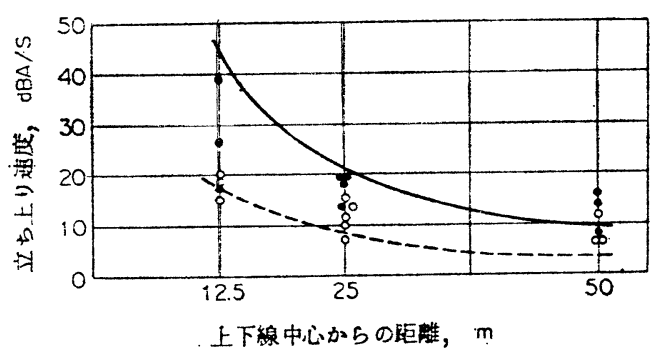

図-16 騒音レベルの立ち上り速度〔実線は二重音源 モデル，破線は有限長線音源 モデルによる 計算值; 黒丸は防音壁 $(1.9 \mathrm{~m})$ があり, 白丸 はない場合; 盛土・高架 $(6 \sim 8 \mathrm{~m})$ の場合 で, 測定点は地上 $1.3 \mathrm{~m}$; 新幹線, 速度 200 $\mathrm{km} / \mathrm{h}\rceil^{17)}$

度でみれば，連続二重音源と有限長線音源モデルとの中 間の特性を示すが，指向性（図-15）, 距離減衰からみる と，連続二重音源モデルに近い特性を示すと言われてい $る^{17)}$.

\section{5. 面音源の距離減衰}

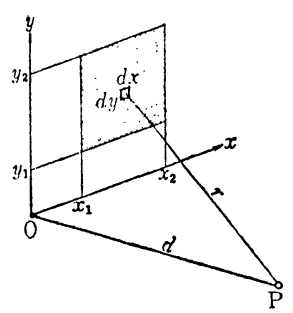

一定の面積をあった空や壁 を通して騒音が伝搬する場 合，非干渉性の点音源が面状 に無数に分布しそれぞれが半 球面波伝搬をしていると仮定 して誘導されてる.いま，図 -17 に示すような長方形面音 図-17 長方形面音源 ${ }^{18)}$ 源を考えれば，受音点 $\mathrm{P}$ 亿お ける強さを $\mathrm{I}_{\mathrm{A}}$ とすれば,

$$
\begin{aligned}
I_{A} & =\int_{x_{1}}^{x_{2}} \int_{y_{1}}^{y_{2}} \frac{W_{A} \cdot d x d y}{2 \pi r^{2}} \\
& =\frac{W_{A}}{2 \pi} \int_{x_{1}}^{x_{2}} \int_{y_{1}}^{2 y} \frac{d x d y}{\left(d^{2}+x^{2}+y^{2}\right)}
\end{aligned}
$$

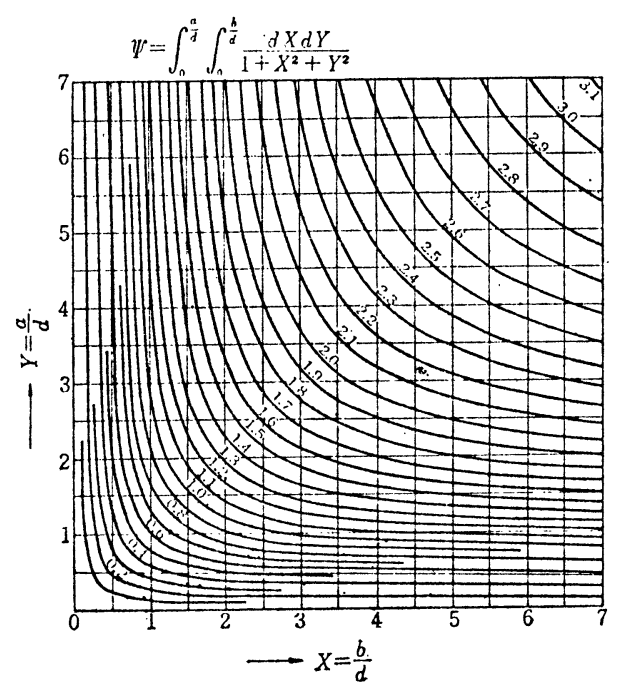

図-18 長方形面音源の $\varphi\left[(36)\right.$ 式]を求める図表 ${ }^{18)}$
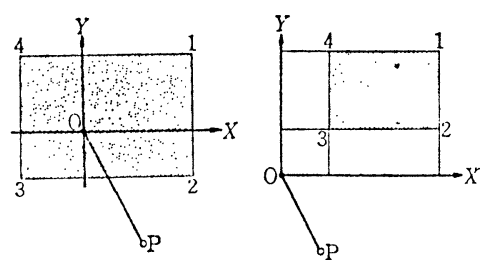

$\Psi=\Psi_{1}+\Psi_{2}+\Psi_{8}+\Psi_{4} \quad \Psi=\Psi_{1}-\Psi_{2}+\Psi_{8}-\Psi_{4}$

図-19 一般の $\Psi$ [36)式 $]$ 值の 3 求め方. 受音点 $\mathrm{P}$ より長方形音源1・2・3・4の面に垂線を下して $\mathrm{O}$ とし，乙れを図-18の原点として, $1 \cdot 2 \cdot 3 \cdot 4$ 各点に応ずる $\Psi$ をそれぞれ $\Psi_{1}, \Psi_{2}, \Psi_{3}, \Psi_{4}$ とすれば図に記入した方法によって簡単に 求められる181.

ただし， W A は単位面積あたりのパワーである. 式(35)の 積分項の計算に資するため, 計算図表（図-18） が求め られている(18). てれは, $\mathrm{x}_{1}=0, \mathrm{y}_{1}=0, \mathrm{x}_{2}=\mathrm{a}, \mathrm{y}_{2}=\mathrm{b}$ の ときについて, 距離 $\mathrm{d}$ を単位として,

$$
\Psi=\int_{0}^{\mathrm{a} / \mathrm{d}} \int_{0}^{\mathrm{b} / \mathrm{d}} \frac{\mathrm{dXdY}}{1+\mathrm{X}^{2}+\mathrm{Y}^{2}}
$$

を数值積分した結果である。

一般の場合は，図-1918) に示す方法で算出できる. 受 音点における音圧レベル SPLA

$$
\mathrm{SPL}_{\mathrm{A}}=\mathrm{PWL}_{\mathrm{A}}-10 \log _{10} 2 \pi+10 \log _{10} \Psi
$$
となる・

以上は，面音源を構成する微少点音源が無指向性であ ると仮定して誘導されたあのであるが，指向性をあたす ため, 微少点音源から, 面に対する法線方向の, 単位立 


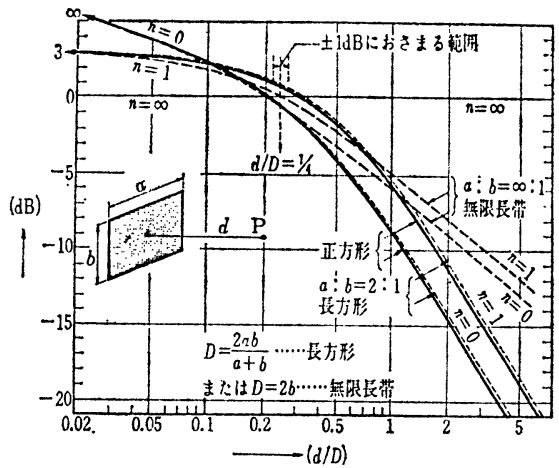

図-20 長方形面音源中心軸上の距離减衰

体角, 単位面積あたりの放射パワーを $\mathrm{J}_{0}$ (単位は watt/ $\mathrm{m}^{2} /$ steradian で, 光の場合の輝度に相当する), それと 角 $\theta$ 方向へのそれを $\mathrm{J} \theta$ (同) とし，

$$
\mathrm{J} \theta=\mathrm{J}_{0} \cos ^{\mathrm{n}} \theta
$$

とする試みが行われている18). このとき， $\mathrm{n}=0$ のとき は無指向性, $\mathrm{n}=\infty$ のときは平面波となる. 又, 面音源 の単位面積あたりの放射パワー $\mathrm{W}_{\mathrm{A}}\left(\mathrm{watt} / \mathrm{m}^{2}\right)$ は,

$$
\mathrm{W}_{\mathrm{A}}=\int_{0}^{\pi / 2} \mathrm{~J} \theta \cdot 2 \pi \sin \theta \cdot \mathrm{d} \theta=\frac{2 \pi \mathrm{J}_{0}}{\mathrm{n}+1}
$$

となる・

長方形面音源 $(\mathrm{a} \times \mathrm{b})$ の中心軸上 $\mathrm{d}$ の 距離にある受 音点 $\mathrm{P}$ における音の強さは,

$$
I_{A}=4 \int_{0}^{b / 2} \int_{0}^{a / 2} \frac{J \theta}{d^{2}+x^{2}+y^{2}} d x d y
$$

となる・

$\mathrm{n}=0$ のときは,

$$
\mathrm{I}_{\mathrm{A}}=\frac{2 \mathrm{~W}_{\mathrm{A}}}{\pi} \int_{0}^{\mathrm{b} / 2} \frac{1}{\sqrt{\mathrm{d}^{2}+\mathrm{y}^{2}}} \tan ^{-1} \frac{\mathrm{a}}{2 \sqrt{\mathrm{d}^{2}+\mathrm{y}^{2}}} \mathrm{dy}
$$

$\mathrm{n}=1$ のときは

$$
I_{A}=\frac{4 W_{A}}{\pi} \tan ^{-1} \frac{a b}{2 d \sqrt{4 d^{2}+a^{2}+b^{2}}}
$$

\section{として求められている18).}

$\mathrm{n}=1$ の場合, 音圧レベル $\mathrm{SPL}_{\mathrm{A}}$ は,

$$
S P L_{A}=P W L_{A}+10 \log _{10}\left(\frac{4}{\pi} \tan ^{-1} \frac{a b}{2 d \sqrt{4 d^{2}+a^{2}+b^{2}}}\right)
$$

として与えられる・計算例を図-2018) に示した。

実用的には，長方形音源の長辺の長さを $\mathrm{a}$ ，短辺の長 さを $\mathrm{b}$ とすれば， $\mathrm{d}$ が $\mathrm{b} / \pi$ までは， SPLA
せず， $d$ が b/ $\pi$ から $\mathrm{a} / \pi$ まで の範囲では，無限長線音源の減衰 $(-3 d B / d d), \quad d か ゙ a / \pi$ より遠 距離の場合 $(-6 \mathrm{~dB} / \mathrm{dd})$ の減衰 を示すとして，概算するととがし ばしば行われている19).

\section{6. 立体音源の距離減衰}

実際にしばしば遭遇する直方体音 源について考察すれば, これを，指 向性をむった各面音源の和として計算するのはかなり煩 頊なので，図-21に示すように，直方体から等距離にあ る包絡線上では, 音圧は均一であると仮定し，乙の場合 の音圧レベル SPL を次式で与えている20,21).

$$
\begin{aligned}
\mathrm{SPL}= & \mathrm{PWL}-\operatorname{10log}_{10}\{\mathrm{AB}+2 \mathrm{H}(\mathrm{A}+\mathrm{B}) \\
& +\pi \mathrm{d}(\mathrm{A}+\mathrm{B})+2 \pi \mathrm{d}(\mathrm{H}+\mathrm{d})\} \\
= & \text { SPL } 0 \\
- & 10 \log _{10}\left\{1+\frac{\pi \mathrm{d}(\mathrm{A}+\mathrm{B})+2 \pi \mathrm{d}(\mathrm{H}+\mathrm{d})}{\mathrm{AB}+2 \mathrm{H}(\mathrm{A}+\mathrm{B})}\right\}
\end{aligned}
$$

ただし，SPL。 は音源表面の平均音圧レベル， $\mathrm{d}$ は音 源の端加らの距離, $\mathrm{A}, \mathrm{B}, \mathrm{H}$ は, それぞれ, 音源の長 さ，幅，及び高さである.

なお，直方体から等距離にある包絡線上の音圧は均一 であるとの仮定は，無響室で模型実験を行い，ほぼ成立 することを確認している，と称している. 20,21

\section{7. あとがき}

以上の距離減衰のほかに，過剰減衰 (excess attenuation）及び異常伝播を考慮しなければならない. 過剰減衰としては，空気，地面による吸収のほかに， 草, 樹木, 障害物等による減音, 異常伝播としては, 気 象条件 (気温, 湿度, 風向, 風速等) の時間的・空間的 な変動（ことに垂直構造）並びに複雑な反射面の影響等 が考えられる.乙れら，すべてにわたって，解析的な定 量化が行われている訳ではなく，今後の調査・研究にま たねばならない部分も多いが，騒音のアセスメントに関 しては極めて重要な問題であり, 稿を改める機会を得た いと思っている。

\section{参考 文 献}

1) 五十嵐寿一 : 航空機騷音問題, 日音会誌, 26, 261 266, 1970.

2) Regional Airport System Study, Environmental Studies, Aviation Noise Evaluations and Projections San Francisco Bay Region, BBN, 1971.

3 ) 山本剛夫 : 航空機騒音の現状と対策, 土木学会関西支部講 
習会テキスト。騷音・振動公害, 1974.

4) A Study of the Magnitude of Transportation Noise Generation and Potential Abatement, Vol. III, Airport/ Aircraft System Noise, Final Report, No. OST-ONA71-1, Dept. Transport., 1970.

5 ) 庄司光, 山本剛夫, 中村隆一 : 街頭騒音とくに交通騒音に 関する研究，日音会誌，19，97～105，1963.

6) Johnson,D. R., and Saunders, E. G. : The Evaluation of Noise from Freely Flowing Road Traffic, J. Sound \& Vib., 7, 287 309, 1968.

7 ）日本音響学会 : 道路交通騷音の予測計算方法に関する研究 報告書, 1975 .

8 ) 石井聖光 : 道路交通騒音予测計算方法に関する研究（その 1)，実用的な計算式について，日音会誌， $31 ， 507 \sim 517$, 1975.

9) Takagi, K.,Hiramatsu, K., Yamamoto, T., and Hashimoto, K. : Investigations on Road Traffic Noise Based on an Exponentially Distributed Vehicles Model, Single Line Flow of Vehicles with Same Acoustic Power, J. Sound \& Vib., 36, 417 431, 1974.

10) 高木興一：自動車騒音の予測と対策, 土木学会関西支部講 習会テキスト，騒音・振動公害，1974。

11) 高木興一：数学的モデルに基うくく予測, 日本音響学会, 「道路交通騷音の予测に扔ける数学的モデルと評価量につ 々て」中に揭載, 1975.

12）高木興一, 平松幸三, 山本剛夫, 橋本和平 : 道路騷音の $レ$
ベル変動に 関する考察（パワーレベルが正規分布する場 合), 日音講集, $317 \sim 318$, June 1974.

13）高木興一, 平松幸三, 山本剛夫 : 道路騷音のレベル変動に 関する考察 (アーラン分布 モデルについての一考察), 日 音講集, 67〜68, May, 1976.

14) A Study of the Magnitude of Transportation Noise Generation and Potential Abatement, Vol. V, Train System Noise, Final Report, No. OST-ONA-71-1, Nov., 1970.

15) 山本剛夫 : 列車による騒音・振動の特性と環境問題（騒音 の部), 土木学会関西支部講習会テキスト，騷音・振動に 関する環境問題, 1976.

16）井川敬之助：鉄道車輛の走行車外騒音の計算モデル，日音 講集, 213 214, Nov., 1968.

17）日本国有鉄道 : 新幹線騷音振動レポート(1), 1973.

18）日本音響材料協会編：騒音対策 ハンドブック，技報堂, 1966.

19）通産省監修: 新版公害防止の技術と法規, 騒音編, 丸善, 1975.

20) 古山雪, 斉藤保夫, 松浦時治, 深津智 : プラントの騒音防 止計画, 三菱重工技報, $8(2), 1 \sim 9,1971$.

21) Saito, Y. and Ookura, K. : Calculation of Noise Propagation Outdoors in Planning for Noise Control of Industrial Plants, Inter-Noise 75 Proceedings, E-6, Sendai, 243 246, Aug. 1975

\section{最 新 刊

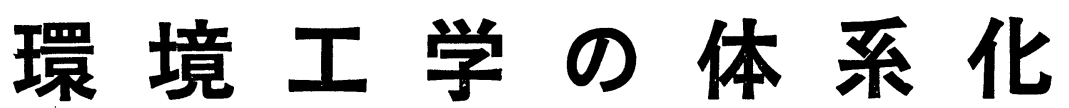

一環境アセスメントとエコロジカル・プランニングの基礎理論—

\section{吉川 博 也著}

\section{$<$ 内容 目 次 $>$ 章 環境総合化理論}

1 章 環境工学のパラダイム

1. 新しい体系化の必要性

2. 問題解決型総合科学のあり方

3. フレーム・ワークの提案

2 章 環境工学の概念

1. 環境工学の位置づけと体系

2. 生態学亡環境工学

3. 環境の同定

3 章 環境分析理論

1. 発生メカニズム論

2. 現象プロセス論

3. 影響特性論

4. 環境制御論

5. 環境測定論
1. 環境解析論

2. 環境計画・設計論

3. 環境の支配原理の解明

\section{環 境 技 術 研 究 会}

